\title{
Effect of Natural Antioxidants Agents on Bond Strength to Bleached Enamel
}

\author{
Larissa Fernandes da Costa, Marta Cléa Costa Dantas, Amanda Cypriano Alves*
}

Department of Dental Clinic, Dental School, UFRJ - Federal University of Rio de Janeiro, Rio de Janeiro, 21941-617, RJ, Brazil

Received May 1, 2020; Revised June 9, 2020; Accepted June 16, 2020

Copyright@2020 by authors, all rights reserved. Authors agree that this article remains permanently open access under the terms of the Creative Commons Attribution License 4.0 International License

\begin{abstract}
Dental bleaching is a procedure performed on the enamel surface to provide harmony and aesthetics to the smile. It is carried out through the use of bleaching agents, which presents as products in mechanism of action, water and oxygen molecules - in which residual oxygen is associated with a possible reduction in bond strength values (BS) of the teeth submitted to bleaching preventing the effectiveness of the adhesive procedure. The purpose of this review was to analyze the data available in the literature on this subject, since the use of antioxidants and the way they are applied in clinical practice seems to act significantly in the BS values of bleached teeth. Database searches were performed with descriptors associated with bleaching and antioxidants, analyzing in particular natural antioxidants and their laboratory and clinical action in dentistry. The results obtained varied according to the compound used, the concentration, the application time and the specific methodology of each research, however it is possible to observe the significant increase in the BS of teeth that were submitted to the antioxidant treatment. Thus, it is possible to observe the importance of studying the mechanism of action that influences the adhesive procedure and the way in which antioxidants are applied to reverse this impasse.
\end{abstract}

Keywords Dental Bleaching, Bond Strength, Antioxidants

\section{Introduction}

Dental bleaching is the procedure performed by dental surgeons in a simple and non-invasive way in patients who seek a harmonic and aesthetic appearance of the smile, using bleaching agents on the surface of the dental enamel $[1,2]$.

The bleaching agents most used today are hydrogen peroxide and carbamide peroxide, whose mechanism of action is the oxidation capacity of the pigment molecules responsible for discoloration, making it possible to perform this procedure in a clinical, homemade or combined manner [3].

The redoxing capacity that promotes whitening results in water and oxygen molecules, which are gradually eliminated from the dental structure. The residues of this phenomenon act on the enamel pigmented organic molecules by attacking their double bonds [4].

However, despite the proper performance of the technique, peroxide residues on the dental surface are present and, thus, can inhibit adhesive polymerization [5], which could influence the bond strength values due to the residual oxygen in the subtract.

The bond strength values can be reduced considerably due to the residual oxygen in the dental substrate, making it possible to reverse this effect with the use of antioxidants in order to guarantee the increase in adhesion between the restorative material and the enamel [6].

According to Alhasyimi et al., [7] the application of synthetic antioxidants, such as sodium ascorbate, can significantly increase the bond strength values after bleaching. However, studies report that the efficiency of synthetic antioxidants may be lower when compared to some natural antioxidants, such as mangosteen extract and Indian gooseberry $[8,9]$.

The objective of this study was to summarize the influence of natural antioxidants obtained from natural extracts on bond strength in bleached teeth submitted to restorative treatments.

\section{Materials and Methods}

A PubMed search was carried out for the years between 2010 and 2020 to identify publications on influence of natural antioxidants on bond strength in bleached teeth submitted to restorative treatments. The search would poke around Keywords: such as "(dental bleaching) AND (bond) AND (restorative) AND (antioxidants) AND 
(natural)”. The four natural antioxidants selected were: (a) grape seed extract; (b) green tea extract; (c) mangosteen peel extract; and (d) AMLA (Phyllanthus emblica) extract.

The selected criteria for inclusion within the literature search were: (1) in vitro studies; (2) antioxidants obtained from nature extracts, (3) the bonding substrate. We did not include articles that presented data related to clinical research and not available in full. The articles of the present study were selected from titles and full abstracts.

\section{Results}

It was possible to find several studies that indicated the anticarcinogenic, antibacterial and antioxidant effects of these natural extracts. Featuring non-cytotoxic effects, easily available and accessible. In addition, some of these natural extracts have superior antioxidant properties than sodium ascorbate. The results found are shown in table 1.

Table 1. Summarizes the Descriptive Properties of the Studies

\begin{tabular}{|c|c|c|c|c|c|c|}
\hline Article Title & Author & Year & Journal & $\begin{array}{c}\text { Extract } \\
\text { Category }\end{array}$ & Objective & Result \\
\hline $\begin{array}{l}\text { Effect of Grape Seed Extract on } \\
\text { the Bond Strength of Bleached } \\
\text { Enamel }\end{array}$ & $\begin{array}{l}\text { Vidhya } \\
\text { et al., }\end{array}$ & 2011 & $\begin{array}{l}\text { Oper } \\
\text { Dent. }\end{array}$ & Grape Seed & $\begin{array}{l}\text { Assess the } \\
\text { neutralizing effect of } \\
\text { grape seed extract on } \\
\text { the bond strength of } \\
\text { bleached enamel }\end{array}$ & $\begin{array}{l}\text { Significantly higher } \\
\text { shear bond } \\
\text { strength values were } \\
\text { observed in teeth treated } \\
\text { with } \\
\text { proanthocyanidin. }\end{array}$ \\
\hline $\begin{array}{l}\text { Use of Grape Seed Extract For } \\
\text { Improving the Shear Bond } \\
\text { Strength of Total-etching } \\
\text { Adhesive to Bleached Enamel }\end{array}$ & $\begin{array}{l}\text { Xu et } \\
\text { al., }\end{array}$ & 2018 & $\begin{array}{c}\text { Dent } \\
\text { Mater J. }\end{array}$ & Grape Seed & $\begin{array}{l}\text { Assert if grape seed } \\
\text { extract can restore the } \\
\text { shear bond strength of } \\
\text { total-etching adhesive } \\
\text { to enamel immediately } \\
\text { after bleaching. }\end{array}$ & $\begin{array}{l}\text { The grape seed extract } \\
\text { can restore the shear } \\
\text { bond strength } \\
\text { compromised after } \\
\text { bleaching in } 1 \text { min if the } \\
\text { concentration is } \geq 5 \% \text {. }\end{array}$ \\
\hline $\begin{array}{l}\text { A comparative evaluation of } \\
\text { the three different antioxidant } \\
\text { treatments on the bond strength } \\
\text { of composite resin to bleached } \\
\text { enamel: An in vitro study. }\end{array}$ & $\begin{array}{l}\text { Nair et } \\
\text { al., }\end{array}$ & 2019 & $\begin{array}{l}\text { J Cons } \\
\text { Dent. }\end{array}$ & Grape Seed & $\begin{array}{l}\text { Investigate the effect } \\
\text { of three different } \\
\text { antioxidant treatments } \\
\text { on the bond strength of } \\
\text { composite resin to } \\
\text { bleached enamel. }\end{array}$ & $\begin{array}{l}\text { The mean bond strength } \\
\text { was significantly higher } \\
\text { which indicated that } \\
\text { immediate application of } \\
\text { proanthocyanidin } \\
\text { showed higher bond } \\
\text { strength after bleaching. }\end{array}$ \\
\hline $\begin{array}{l}\text { Comparative evaluation of } \\
\text { effects of natural antioxidants } \\
\text { on the shear bond strength of } \\
\text { composite resin to bleached } \\
\text { enamel. }\end{array}$ & $\begin{array}{l}\text { Rana et } \\
\text { al., }\end{array}$ & 2019 & $\begin{array}{l}\text { Indian J } \\
\text { Dent } \\
\text { Res. }\end{array}$ & Green Tea & $\begin{array}{l}\text { Compare the effects of } \\
\text { natural antioxidants on } \\
\text { the shear bond } \\
\text { strength of composite } \\
\text { resin to bleached } \\
\text { enamel. }\end{array}$ & $\begin{array}{l}\text { There were statistically } \\
\text { significant differences } \\
\text { between shear bond } \\
\text { strength of control } \\
\text { groups and experimental } \\
\text { groups, but no } \\
\text { significant difference in } \\
\text { bond strength was } \\
\text { observed among the } \\
\text { antioxidants used. }\end{array}$ \\
\hline $\begin{array}{l}\text { Effects of green tea application } \\
\text { time on bond strength after } \\
\text { enamel bleaching }\end{array}$ & $\begin{array}{l}\text { Ozelin } \\
\text { et al., }\end{array}$ & 2014 & $\begin{array}{c}\text { Braz } \\
\text { Dent J. }\end{array}$ & Green Tea & $\begin{array}{l}\text { Evaluate the effect of } \\
\text { green tea application } \\
\text { time on the bond } \\
\text { strength of enamel } \\
\text { after enamel } \\
\text { bleaching. }\end{array}$ & $\begin{array}{l}\text { The bond strength values } \\
\text { were higher than the } \\
\text { value in the bleached } \\
\text { group only when the } \\
\text { antioxidants were } \\
\text { applied for } 60 \mathrm{~min} \text {. }\end{array}$ \\
\hline $\begin{array}{l}\text { Can green tea be used to } \\
\text { reverse compromised bond } \\
\text { strength after bleaching? }\end{array}$ & $\begin{array}{l}\text { Berger } \\
\text { et al., }\end{array}$ & 2013 & $\begin{array}{l}\text { Eur J } \\
\text { Oral } \\
\text { Sci. }\end{array}$ & Green Tea & $\begin{array}{l}\text { Evaluate the } \\
\text { antioxidant effect of } \\
\text { green tea on } \\
\text { microtensile bond } \\
\text { strength to bleached } \\
\text { enamel. }\end{array}$ & $\begin{array}{l}\text { Green tea can be used as } \\
\text { an alternative } \\
\text { antioxidant on bleached } \\
\text { enamel before bonding } \\
\text { procedures. }\end{array}$ \\
\hline $\begin{array}{l}\text { Effect of mangosteen peel } \\
\text { extract as an antioxidant agent } \\
\text { on the shear bond strength of } \\
\text { orthodontic brackets bonded to } \\
\text { bleached teeth. }\end{array}$ & $\begin{array}{l}\text { Alhasyi } \\
\text { mi, et } \\
\text { al., }\end{array}$ & 2018 & $\begin{array}{l}\text { Dental } \\
\text { Press J } \\
\text { Orthod. }\end{array}$ & Mangosteen & $\begin{array}{l}\text { To determine and } \\
\text { prove the effect of } \\
\text { mangosteen peel } \\
\text { extract to reverse the } \\
\text { reduced shear bond } \\
\text { strength of orthodontic } \\
\text { brackets after } \\
\text { bleaching. }\end{array}$ & $\begin{array}{l}\text { The shear bond strenght } \\
\text { in the group treated with } \\
40 \% \text { MP gel was } \\
\text { significantly higher ( } 7.93 \\
\pm 1.92 \mathrm{MPa} \text { ) than other } \\
\text { groups treated with } \\
\text { antioxidants. }\end{array}$ \\
\hline $\begin{array}{l}\text { A comparison of the effect of } \\
\text { application of sodium ascorbate } \\
\text { and amla (Indian gooseberry) } \\
\text { extract on the bond strength of } \\
\text { brackets bonded to bleached } \\
\text { human enamel: An In vitro } \\
\text { study. }\end{array}$ & $\begin{array}{c}\text { Keni et } \\
\text { al., }\end{array}$ & 2018 & $\begin{array}{l}\text { Indian J } \\
\text { Dent } \\
\text { Res. }\end{array}$ & $\begin{array}{c}\text { Indian } \\
\text { Gooseberry }\end{array}$ & $\begin{array}{l}\text { Compare the efficacy } \\
\text { of a naturally } \\
\text { occurring antioxidant } \\
\text { (gooseberry) and } \\
\text { sodium ascorbate in } \\
\text { normalizing the bond } \\
\text { strength of enamel to } \\
\text { prebleached levels. }\end{array}$ & $\begin{array}{l}\text { Treatment with } \\
\text { gooseberry extract did } \\
\text { improve the bond } \\
\text { strength but was not as } \\
\text { effective as sodium } \\
\text { ascorbate post bleaching. }\end{array}$ \\
\hline
\end{tabular}




\subsection{Vitis vinifera - Grape Seed Extract}

Grape seed extract contains 98\% proanthocyanidin and are described as oligomeric complexes, which contains multiple electron donor sites (hydroxyl sites) that allow it to bind to free radicals by donating its hydrogen atoms and increase the antioxidative effect by esterification of polyphenols in proanthocyanidin complexes $[10,11]$.

Vidhya et al., [12] studied the neutralizing effect of the oligomeric proanthocyanidin complexes, which is derived from the grape seed, and sodium ascorbate, on the bond strength of the bleached enamel with 38\% hydrogen peroxide. Human upper central incisors were randomly divided into four groups, based on the antioxidant used. The groups were: not received any bleaching treatment (control); bleached with 38\% hydrogen peroxide gel for ten minutes, without using antioxidants; bleached followed by treatment with $10 \%$ sodium ascorbate solution; bleached followed by the use of a $5 \%$ proanthocyanidin solution. With the exception of the control group, the others groups were divided into two subgroups, with the results of the antioxities being evaluated immediately after bleaching and after two weeks after bleaching. Both 10\% sodium ascorbate and 5\% proanthocyanidin groups showed significantly higher shear strength values than the control group. Among the antioxidants used in this study, $5 \%$ proanthocyanidin showed significantly higher shear bond strength values than $10 \%$ sodium ascorbate in both subgroups.

$\mathrm{Xu}$ et al., [13] studied the possibility of increasing the shear strength of bleached teeth with the use of grape seed extract as an antioxidant. The selected groups were: control (not bleaching); bleached without antioxidant treatment; bleached and treated with $2.5 \%$ grape seed extract; at $5 \% ; 10 \%$ and $15 \%$. A decrease significantly in the shear strength values was observed after bleaching in was observed no matter what kind of adhesive or storage condition used. In addition, an assessment of failure modes was performed with classification associated with cohesive failure in the resin compound, enamel or mixed which did not show significant differences in the failure mode. Thus, the study showed that within its limitations, the bond strength of the enamel can be restored by the grape seed extract as long as the concentration used is equal to or greater than $5 \%$.

Nair et al., [10] investigate the effect of three different antioxidant treatments on the bond strength of composite resin to bleached enamel. The Group I: No bleached (control group), Group II: bleached only (no antioxidants), Group III: bleached followed by treatment with sodium ascorbate for $10 \mathrm{~min}$, Group IV: bleached followed by treatment with proanthocyanidin for $10 \mathrm{~min}$, Group V: bleached followed by treatment with A. vera for $10 \mathrm{~min}$. The results of the study indicated that the immediate application of all antioxidants was equally effective in reversing the compromised bond strength. The mean bond strength of Group IV was significantly higher $(\mathrm{P}<0.05)$
$(4.27 \pm 1.86)$ which indicated that immediate application of proanthocyanidin showed higher bond strength after bleaching.

\subsection{Camellia sinensis - Green Tea Extract}

Green tea is obtained from the Camellia sinensis plant and contains flavanols and catechins - which may have greater antioxidant activity than vitamin $\mathrm{C}$ and vitamin $\mathrm{E}$ [14].

Rana et al., [15] compared the effect of using natural antioxidants on the shear bond strength of composite resin to bleached enamel. Five groups were tested, depending on the type of antioxidant used ( $\mathrm{n}=10$ ): (i) Group 1: control (no bleaching), (ii) Group 2: bleaching only, (iii) Group 3: bleaching $+10 \%$ sodium ascorbate (antioxidant), (iv) Group 4: bleaching + green tea, and (v) Group 5: bleaching + white tea. There were statistically significant differences between shear bond strength of control groups (Groups 1 and 2) and experimental groups $(P<0.05)$, but no significant difference in bond strength was observed among the antioxidants used. Therefore, it was possible to conclude that the Application of antioxidants immediately after bleaching showed increased bond strength. Green tea and white tea extract can be used as alternative antioxidants in improving the bond strength of enamel.

Sharafeddin et al., [16] assessed the effect of green tea extract on shear bond strength of resin composite to in-office and home-bleached enamel. According to his findings, the application of antioxidant did not increase the shear bond strength of home-bleached enamel to resin composite but its application increased the shear bond strength of in-office bleached enamel to resin composite.

Ozelin et al., [17] evaluated the effect of green tea application time on the bond strength of teeth whitened with $10 \%$ carbamide peroxide. After clearing, the adhesive procedure was performed and the samples were subjected to microtensile tests, which indicated a difference between the antioxidant treatments when used for 60 minutes - being greater in the group submitted to the green tea treatment. The analysis of the fracture pattern was analyzed using a stereoscopic magnifying glass, with adhesive failures predominating at the expense of mixed or cohesive failures. Therefore, according to the methodology and the results obtained, it was observed that the $10 \%$ green tea gel reversed the adverse effects associated with bond strength only when applied for 1 hour, obtaining effects similar to sodium ascorbate.

Berger et al., [18] evaluated the antioxidant effect of green tea on the enamel of teeth whitened with $10 \%$ carbamide peroxide. Third molars were randomly divided into six groups. After the procedures for whitening and antioxidant treatment, the adhesive procedure was performed and the teeth were submitted to the microtensile test by means of a universal testing machine, which had significant effects in reversing the bond strength of the groups submitted to the tea treatment. 
green. The analysis of the fracture pattern of the enamel surface was evaluated by scanning electron microscopy, showing a greater pattern of mixed failures. The results showed that the antioxidant agents only had beneficial effects when used after the whitening treatment and within the limitations of the study, the treatment with green tea showed satisfactory results in maintaining the resistance of the enamel union.

\subsection{Garcinia mangostana L - Mangosteen Extract}

The mangosteen, or Garcinia mangostana L. of the family Clusiaceae is a natural tree from Southeast Asia, which comes from a fruit with the same name, the mangosteen. The mangosteen extract has a complex chemical composition, with bioactive compounds, such as xanthones, tannins and flavonoids, presenting anti-toxicity, anti-allergenic, anti-inflammatory, antiviral and antibacterial activities [19].

Studies show that the extract of the mangosteen peel (MP) acts to control the oxidation reaction of free radical molecules, being compared to other antioxidants - such as ascorbic acid [20, 21].

Alhasyimi, et al., [20] studied the effect of the MP extract in order to reverse the decreased resistance of bonded orthodontic brackets after bleaching with 40\% hydrogen peroxide. Premolars were divided into six groups: negative control (without bleaching); positive control (with whitening and without treatment); whitening and treatment with $10 \%$ sodium ascorbate; whitening and treatment with 10\% MP extract gel; $20 \%$ and $40 \%$. After the antioxidant treatment, orthodontic brackets were bonded with resin-modified glass ionomer cement and the teeth were subjected to shear resistance test and the brackets were detached to check the remaining adhesive index using a stereoscopic microscope. The results showed was significant of shear strength (SBS) difference $(\mathrm{p}<0.001)$ between groups. The group without bleaching showed significantly higher SBS (8.19 $\pm 2.26 \mathrm{MPa})$ compared to others, while SBS in the group treated with $40 \%$ mangosteen gel was significantly higher $(7.93 \pm 1.92 \mathrm{MPa})$ than other groups treated with antioxidants. Thus, the study states that the use of MP extract is effective in reversing the bond strength, requiring a greater study of the compound for possible application in clinical practice.

Alhasyimi et al., [21] evaluated the effect of MP extract on the post-bleaching tensile bond strength (TBS) of brackets. experimental in vitro study conducted on a total of 120 maxillary first premolar teeth randomly divided into six groups $(n=20)$ as follows: negative-control (NC: no bleaching), positive-control (PC: bleaching + no treatment), and the treatment groups (bleaching $+10 \%$ sodium ascorbate (SA), 10\% (MP10), 20\% (MP20) and 40\% (MP40) MP extract gel).

There was a significant TBS difference $(P=0.001)$ between the various groups. The PC group showed the significantly highest TBS compared to the others (8.33 \pm 3.92 $\mathrm{MPa})$, whereas NC demonstrated the lowest (4.15 \pm $2.27 \mathrm{MPa})$. The TBS value of the MP40 group (7.87 \pm $3.26 \mathrm{MPa}$ ) was considerably higher than other groups treated with antioxidants. The failure of orthodontic brackets using MP extract occurred at the adhesive-bracket Therefore, it was possible to conclude that application of $40 \%$ MP extract as an antioxidant after bleaching was effective in reversing the reduced post-bleaching tensile bond strength (TBS) of orthodontic brackets [21].

\subsection{Phyllanthus emblica - Indian Gooseberry}

Phyllanthus emblica is a medicinal plant used due to its composition that has a significant pharmacological action through phenolic compounds belonging to groups such as flavonoids and procyanidins - characterizing the possibility of acting as an antioxidant [22].

Keni et al., [9] aimed to study comparatively a synthetic antioxidant (sodium ascorbate) and a natural antioxidant (Indian currant) and their effectiveness in increasing the bond strength of orthodontic brackets in teeth bleached with carbamide peroxide to $16 \%$. Pre-molars extracted for orthodontic reasons were used and divided into four groups: control group in which the brackets were adhered to the unclear enamel; group in which the brackets were adhered to the whitened enamel; group in which the brackets were adhered to the whitened enamel after antioxidant treatment with $10 \%$ sodium ascorbate and group in which the brackets were whitened after antioxidant treatment with Indian gooseberry. The shear strength test was performed using a universal testing machine. The results showed an increase in the bond strength values in the groups treated with antioxidant, however the Indian currant showed a significantly lower value when compared to sodium ascorbate. Thus, currant was not as effective in reversing the bond strength compared to sodium ascorbate.

Kumar at al., [23] discussed the therapeutic significance activity of plants extract and individual compounds in the extracts of P. emblica. According to the authors, its antioxidant activity was associated with the free radical-scavenging activity of plants extract and individual compounds in the extracts of $P$. emblica, and defined that understanding of metabolic pathways responsible for biosynthesis of these compounds in $P$. emblica is very important.

\section{Discussion}

The use of biomaterials is the target of dental research in order to provide due knowledge about its use, being fundamental for innovation and development of dentistry through the application of such materials to benefit clinical practice. 
Regarding antioxidant biomaterials and their use in increasing of the bond strength of bleached teeth, it is observed that a variety of active ingredients are chosen with a common purpose. However, the response of each application varies according to the material selected, the concentration, the preparation of the specimens, the time, among other variables. Therefore, it is necessary to have a correct understanding of the materials and the way they are used and applied in clinical practice. $[8,11,23]$

Grape seed extract contains oligomers proanthocyanidin complexes that can eliminate free radicals and can be used as an antioxidant. [10,11,13] The study carried out by S Vidhya et al.,[12] was done in a comparative way with sodium ascorbate and the specimens were not submitted to antioxidant treatment instantly, being the result more favorable to the use of the natural antioxidant in detriment of the synthetic one. In contrast, the study by Xu et al.,[13] used only the natural antioxidant, but with different concentrations and the positive results were observed from the use of the $5 \%$ extract, concluding that the use of the seed extract of grape would be effective with concentrations equal to or greater than that.

The analysis of green tea in the study by Ozelin et al., [17] was performed comparatively with sodium ascorbate, where the antioxidant treatment was performed in groups with different exposure intervals. The results of microtensile tests showed that the action of $10 \%$ green tea was similar to that of sodium ascorbate only when used for 60 minutes. While the study by Berger et al., [18] which used $10 \%$ green tea gel and was also performed comparatively with sodium ascorbate, showed, through microtensile tests, significant effects on reversion of the bond strength of the groups submitted to green tea treatment.

The study by Alhasyimi et al., [20] on the use of bark extract MP was made with varying concentrations of the compound in question and in a comparative way with $10 \%$ sodium ascorbate, being subjected to shear strength tests and analysis by stereoscopic microscope, showing variation between the values of the different groups, according to the concentration used - all groups showed a higher value compared to the control group, however the group submitted to $40 \%$ MP extract showed significantly higher results, which emphasized the need for further studies to enable its application in clinical practice.

Keni et al., [9] compared the action of the Indian gooseberry extract with $10 \%$ sodium ascorbate. The shear strength tests showed an increase in the bond strength values of the groups that were submitted to the antioxidant treatment, however the Indian currant showed significantly lower results when compared to the synthetic antioxidant, not having the expected effectiveness.

\section{Conclusions}

From the data obtained in the study, it could be deduced that tooth bleaching is a procedure that presents satisfactory aesthetic results for the patient. However, the mechanism of this procedure promotes a reduction in bond strength - which can be harmful if it is necessary to perform adhesive procedures and, with that, the use of antioxidants is necessary to reverse this condition. Synthetic antioxidants are commonly used for this purpose; however, the use of natural antioxidants has been increasingly studied. It is essential that further studies are carried out in order to explore the application of natural antioxidants for a better use of them.

\section{REFERENCES}

[1] Francci C, Marson FC, Briso ALF, Gomes MN. Clareamento dental - Técnicas e conceitos atuais. Revista da Associação Paulista de Cirurgiões Dentistas. Vol. 64, No. 1, 78-89, 2010.

[2] Haywood VB, Berry TG. Natural tooth bleaching. J Esthet Restor Dent. Fundamentals of Operative Dentistry. A Contemporary Approach. 401-426, 2001.

[3] Faus-Matoses V, Palau-Martínez I, Amengual-Lorenzo J, Faus-Matoses I, Faus-Llácer VJ. Bleaching in vital teeth: Combined treatment vs in-office treatment. Journal of Clinical and Experimental Dentistry. Vol. 11, No. 8, 754758, 2019.

[4] Kwon SR, Wertz PW. Review of the mechanism of tooth whitening. Journal of Esthetic and Restorative Dentistry. Vol. 27, No. 5, 240-57, 2015.

[5] Patusco VC, Montenegro G, Lenza MA, Carvalho AA. Bond strength of metallic brackets after dental bleaching. Angle Orthodontist. Vol. 79, No. 1, 122-6, 2009.

[6] Warol F, Scarparo A, Calazans FS, Barcelos R, Barceleiro MO. Effect of whitening dentifrices containing hydrogen peroxide or carbamide peroxide, in bond adhesion to dental enamel. Journal of Clinical Dentistry and Research. Vol. 15, No. 2, 100-8, 2018.

[7] Alhasyimi A, Pudyani, P; Hafizi I. Effect of mangosteen peel extract as an antioxidant agent on the shear bond strength of orthodontic brackets bonded to bleached teeth. Dental Press Journal of Orthodontics. Vol. 23, No. 5, 58-64, 2018.

[8] Taghvaei M, Jafari SM. Application and stability of natural antioxidants in edible oils in order to substitute synthetic additives. Journal of Food Science and Technology. Vol. 52, No. 3, 1272-82, 2015.

[9] Keni S, Nambiar S, Philip P, Shetty S. A comparison of the effect of application of sodium ascorbate and amla (Indian gooseberry) extract on the bond strength of brackets bonded to bleached human enamel: An In vitro study. Indian Journal of Dental Research. Vol. 29, No. 5, 663-666, 2018.

[10] Nair R, Bandhe S, Ganorkar OK, Saha S, Sial S, Nair A. A comparative evaluation of the three different antioxidant treatments on the bond strength of composite resin to bleached enamel: An in vitro study. Journal of Conservative 
Dentistry. Vol. 22, No. 1, 82, 2019.

[11] Khamverdi Z, Khadem P, Soltanian A, Azizi M. In-Vitro Evaluation of the Effect of Herbal Antioxidants on Shear Bond Strength of Composite Resin to Bleached Enamel. Journal of Dentistry (Tehran). Vol. 13, No. 4, 244-251, 2016.

[12] Vidhya S, Srinivasulu S, Sujatha M, Mahalaxmi S. Effect of Grape Seed Extract on the Bond Strength of Bleached Enamel. Operative Dentistry. Vol. 36, No. 4, 433-8, 2011.

[13] Xu Y, Zhou J, Tan J. Use of grape seed extract for improving the shear bond strength of total-etching adhesive to bleached enamel. Dental Materials Journal, V. 37, No. 2, 325-331, 2018.

[14] Prasanth MI, Sivamaruthi BS, Chaiyasut C, Tencomnao T. A Review of the Role of Green Tea (Camellia sinensis) in Antiphotoaging, Stress Resistance, Neuroprotection, and Autophagy. Nutrients. Vol. 23, No. 11, 2, 2019.

[15] Rana R, Kaushik M, Sharma R, Reddy P, Mehra N. Comparative evaluation of effects of natural antioxidants on the shear bond strength of composite resin to bleached enamel. Indian Journal of Dental Research. Vol. 30, No. 1, 112-116, 2019.

[16] Sharafeddin F, Farshad F, Azarian B, Afshari A. Effect of green tea extract as antioxidant on shear bond strength of resin composite to in-office and home-bleached enamel. 2016; Journal of Dental Biomaterials. Vol. 3, No. 3, 269-275, 2016.

[17] Ozelin AA, Guiraldo RD, Carvalho RV, Lopes MB, Berger
SB. Effects of green tea application time on bond strength after enamel bleaching. Brazilian Dental Journal. Vol. 25, No. 5, 99-403, 2014.

[18] Berger SB, De Souza Carreira RP, Guiraldo RD, Lopes MB, Pavan S, Giannini M,Bedran-Russo AK. Can green tea be used to reverse compromised bond strength after bleaching? European Journal of Oral Sciences. Vol. 121, No. 4, 377-381, 2013.

[19] Rohman A, Rafi M, Alam G, Muchtaridi M, Windarsih, A. Chemical composition and antioxidant studies of underutilized part of mangosteen (Garcinia mangostana L.) fruit. Journal of Applied Pharmaceutical Science. Vol. 9, No. 08, 047-052, 2019.

[20] Alhasyimi AA, Pudyani PS, Hafizi I. Effect of mangosteen peel extract as an antioxidant agent on the shear bond strength of orthodontic brackets bonded to bleached teeth. Dental Press Journal of Orthodontics. Vol. 23, No. 5, 58-64, 2018.

[21] Alhasyimi AA. Antioxidant potency of mangosteen peel extract topical application in reversing reduced orthodontic brackets tensile strength after bleaching. Dental Journal (Majalah Kedokteran Gigi). Vol. 50, No. 4, 199-204, 2017.

[22] Zhao T, Sun Q, Marques M, Witcher M. Anticancer Properties of Phyllanthus emblica (Indian Gooseberry). Oxidative Medicine and Cellular Longevity. Vol. 2015, 950890, 2015.

[23] Kumar A., Singh A, Singh B. Assessment of therapeutic potential of Phyllanthus emblica (Amla): A natural Godsend. International Journal of Cell Science and Bitechnology. Vol. 3, 4-14, 2015. 